\title{
The Economics of Knowledge, Innovation and Systemic Technology Policy
}

There is wide consensus on the importance of knowledge for economic growth and local development patterns. This book proposes a view of knowledge as a collective, systemic and evolutionary process that enables agents and social systems to overcome the challenges of the limits to growth. It brings together new conceptual and empirical contributions, analysing the relationship between demand and supply factors and the rate and direction of technological change. It also examines the different elements that compose innovation systems.

The Economics of Knowledge, Innovation and Systemic Technology Policy provides the background for the development of an integrated framework for the analysis of systemic policy instruments and their mutual interaction with the socio-political and economic conditions of the surrounding environment.

These aspects have long been neglected in innovation policy, as policymakers, academics and the business community have mostly emphasized the benefits of supply-side strategies. However, a better understanding of innovation policies grafted on a complexity-based approach calls for the appreciation of the mutual interactions between both supply and demand aspects, and it is likely to improve the actual design of policy measures.

This book will help readers to understand the foundations and workings of demand-driven innovation policies by stressing the importance of competent and smart demand.

Francesco Crespi is Professor at the Department of Economics of Roma Tre University, and Research Associate at the Bureau of Research on Innovation, Complexity and Knowledge (BRICK), Collegio Carlo Alberto, Italy.

Francesco Quatraro is Asseiate Professor at the University of Nice-Sophia Antipelis, Franee. 
Routledge studies in global competition

Edited by

John Cantwell

Rutgers, the State University of New Jersey, USA

and

David Mowery

University of California, Berkeley, USA

1 Japanese Firms in Europe

Edited by Frédérique Sachwald

2 Technological Innovation, Multinational Corporations and New International

Competitiveness

The case of intermediate countries

Edited by José Molero

3 Global Competition and the

Labour Market

Nigel Driffield

4 The Source of Capital Goods

Innovation

The role of user firms in Japan and Korea

Kong-Rae Lee

5 Climates of Global Competition Maria Bengtsson

6 Multinational Enterprises and Technological Spillovers

Tommaso Perez

7 Governance of International Strategic Alliances

Technology and transaction costs Joanne E. Oxley
8 Strategy in Emerging Markets

Telecommunications establishments in Europe

Anders Pehrsson

9 Going Multinational

The Korean experience of direct investment

Edited by Frédérique Sachwald

10 Multinational Firms and

Impacts on Employment, Trade

and Technology

New perspectives for a new

century

Edited by Robert E. Lipsey and

Jean-Louis Mucchielli

11 Multinational Firms

The global-local dilemma

Edited by John H. Dunning and

Jean-Louis Mucchielli

12 MIT and the Rise of

Entrepreneurial Science

Henry Etzkowitz

13 Technological Resources and the

Logic of Corporate

Diversification

Brian Silverman 
14 The Economics of Innovation, New Technologies and Structural Change Cristiano Antonelli

15 European Union Direct Investment in China Characteristics, challenges and perspectives

Daniel Van Den Bulcke, Haiyan Zhang and Maria do Céu Esteves

16 Biotechnology in Comparative Perspective

Edited by Gerhard Fuchs

17 Technological Change and Economic Performance Albert L. Link and Donald S. Siegel

18 Multinational Corporations and European Regional Systems of Innovation

John Cantwell and

Simona Iammarino

19 Knowledge and Innovation in Regional Industry

An entrepreneurial coalition Roel Rutten

20 Local Industrial Clusters Existence, emergence and evolution

Thomas Brenner

21 The Emerging Industrial Structure of the Wider Europe Edited by Francis McGowen, Slavo Radosevic and Nick Von Tunzelmann
22 Entrepreneurship

A new perspective

Thomas Grebel

23 Evaluating Public Research Institutions

The U.S. Advanced Technology

Program's Intramural Research

Initiative

Albert N. Link and John T. Scott

24 Location and Competition Edited by Steven Brakman and Harry Garretsen

25 Entrepreneurship and Dynamics in the Knowledge Economy Edited by Charlie Karlsson, Börje Johansson and Roger R. Stough

26 Evolution and Design of Institutions

Edited by Christian Schubert and Georg von Wangenheim

27 The Changing Economic Geography of Globalization Reinventing space Edited by Giovanna Vertova

28 Economics of the Firm Analysis, evolution and history Edited by Michael Dietrich

29 Innovation, Technology and Hypercompetition Hans Gottinger

30 Mergers and Acquisitions in Asia A global perspective Roger Y.W. Tang and Ali M. Metwalli 
31 Competitiveness of New Industries

Institutional framework and learning in information technology in Japan, the U.S and Germany

Edited by Cornelia Storz and Andreas Moerke

32 Entry and Post-Entry Performance of Newborn Firms Marco Vivarelli

33 Changes in Regional Firm Founding Activities

A theoretical explanation and empirical evidence

Dirk Fornahl

34 Risk Appraisal and Venture Capital in High Technology New Ventures

Gavin C. Reid and Julia A. Smith

35 Competing for Knowledge Creating, connecting and growing Robert Huggins and Hiro Izushi

36 Corporate Governance, Finance and the Technological Advantage of Nations Andrew Tylecote and Francesca Visintin

37 Dynamic Capabilities Between Firm Organisation and Local Systems of Production

Edited by Riccardo Leoncini and Sandro Montresor

38 Localised Technological Change Towards the economics of complexity

Cristiano Antonelli

39 Knowledge Economies Innovation, organization and location Wilfred Dolfsma
40 Governance and Innovation Maria Brouwer

41 Public Policy for Regional Development

Edited by Jorge Martinez-Vazquez and François Vaillancourt

42 Evolutionary Economic

Geography

Location of production and the

European Union

Miroslav Jovanovic

43 Broadband Economics

Lessons from Japan

Takanori Ida

44 Targeting Regional Economic Development

Edited by Stephan J. Goetz,

Steven C. Deller and

Thomas R. Harris

45 Innovation, Knowledge and Power in Organizations Theodora Asimakou

46 Creativity, Innovation and the

Cultural Economy

Edited by Andy C. Pratt and

Paul Jeffcutt

47 Co-opetition Strategy

Giovanni Battista Dagnino and

Elena Rocco

48 Knowledge Intensive 37

Entrepreneurship and $\quad 38$

Innovation Systems 39

Evidence from Europe $\quad 40$

Edited by Franco Malerba 41

49 Innovation in Complex Social

Systems

Edited by Petra Ahrweiler 
50 Internationalization, Technological Change and the Theory of the Firm Edited by Nicola De Liso and Riccardo Leoncini

51 Territory, Specialization and Globalization in European Manufacturing Helena Marques and Francisco Puig

52 Institutional Diversity and Innovation

Continuing and emerging patterns in Japan and China

Cornelia Storz and

Sebastian Schäfer

53 Innovation and Economic Crisis Daniele Archibugi and Andrea Filippetti

54 The Communications Industries in the Era of Convergence Catherine Mulligan

55 Innovation, Technology and Knowledge Charlie Karlsson, Börje Johansson and Roger R. Stough

56 Evolution of Competition Laws and their Enforcement Pradeep S. Mehta

57 The Economics of Structural Change in Knowledge Francesco Quatraro
58 Economic Geography and the Unequal Development of Regions Jean-Claude Prager and Jacques-François Thisse

59 Social Networks, Innovation and the Knowledge Economy Edited by Isabel Salavisa and Margarida Fontes

60 The Economics of Creativity Ideas, firms and markets Edited by Thierry Burger-Helmchen

61 Epistemic Economics and Organization

Forms of rationality and governance for a discovery oriented economy Anna Grandori

62 Universities, Cities and Regions Loci for knowledge and innovation creation Edited by Roberta Capello, Agnieszka Olechnicka and Grzegorz Gorzelak

63 Strategies for Shaping Territorial Competitiveness Edited by Jesús M. Valdaliso and James R. Wilson

64 The Economics of Knowledge, Innovation and Systemic Technology Policy Edited by Francesco Crespi and Francesco Quatraro 


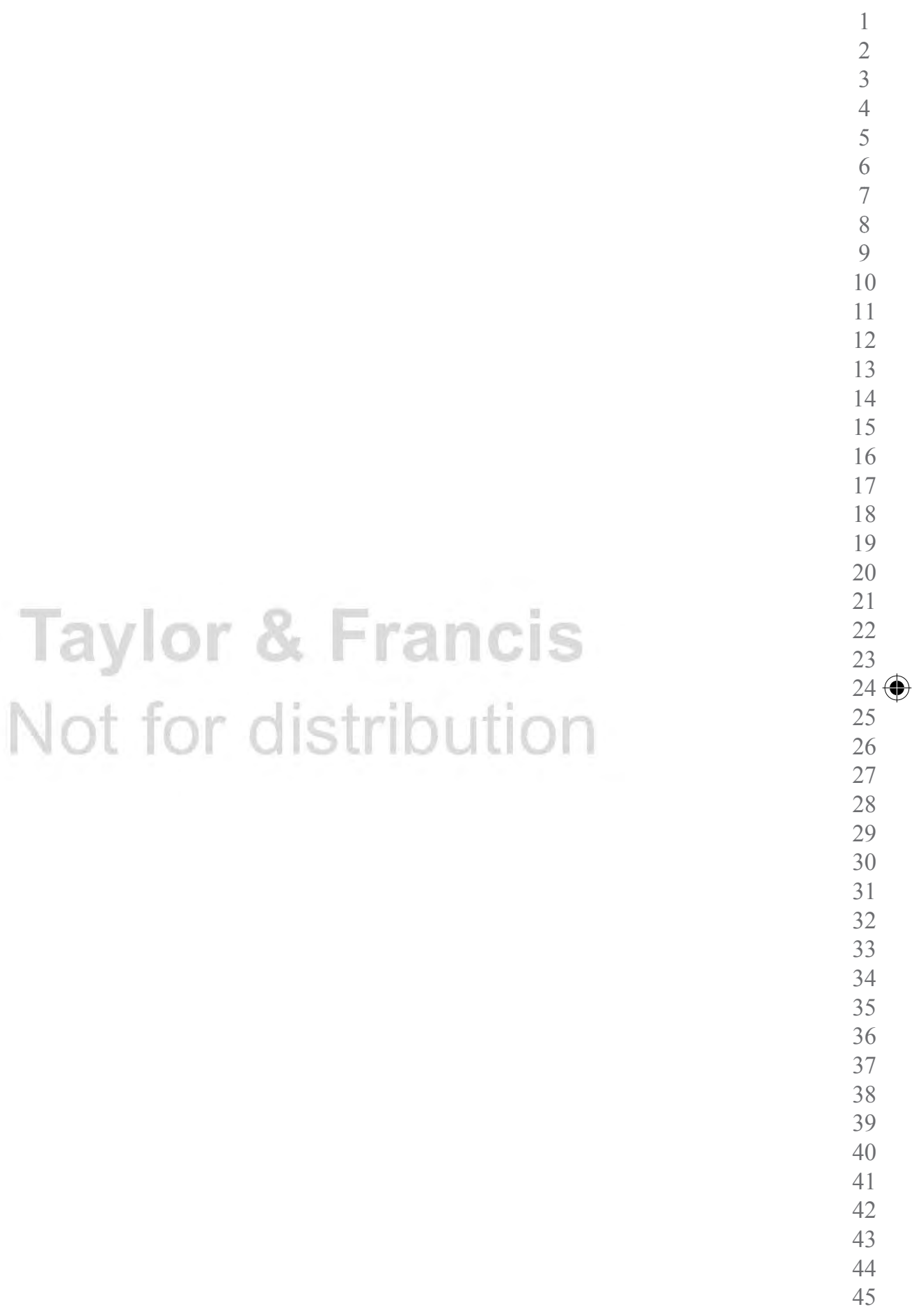




\title{
The Economics of Knowledge, Innovation and Systemic Technology Policy
}

\author{
Edited by \\ Francesco Crespi and \\ Francesco Quatraro
}

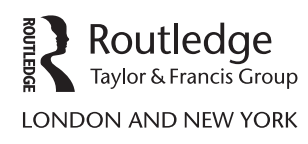


First published 2015

by Routledge

2 Park Square, Milton Park, Abingdon, Oxon OX14 4RN

and by Routledge

711 Third Avenue, New York, NY 10017

Routledge is an imprint of the Taylor \& Francis Group, an informa business

(C) 2015 selection and editorial matter, Edited by Francesco Crespi and Francesco Quatraro; individual chapters, the contributors

The right of the editor to be identified as the author of the editorial matter, and of the authors for their individual chapters, has been asserted in accordance with sections 77 and 78 of the Copyright, Designs and Patents Act 1988 .

All rights reserved. No part of this book may be reprinted or reproduced or utilized in any form or by any electronic, mechanical, or other means, now known or hereafter invented, including photocopying and recording, or in any information storage or retrieval system, without permission in writing from the publishers.

Trademark notice: Product or corporate names may be trademarks or

registered trademarks, and are used only for identification and explanation without intent to infringe.

British Library Cataloguing in Publication Data

A catalogue record for this book is available from the British Library

Library of Congress Cataloging in Publication Data

A catalog record for this book has been requested

ISBN: 978-0-415-70301-7 (hbk)

Typeset in Times New Roman

by Wearset Ltd, Boldon, Tyne and Wear 


\section{Contents}

List of figures $\quad$ xi

List of tables xiv

List of contributors $\quad$ xvi

PART I

Knowledge, innovation and the demand side 1

1 Knowledge, innovation and the different dimensions of systemic technology policy

FRANCESCO CRESPI AND FRANCESCO QUATRARO

2 On the co-evolution of innovation and demand: some policy implications

PIER PAOLO SAVIOTTI AND ANDREAS PYKA

CRISTIANO ANTONELLI AND AGNIESZKA GEHRINGER

4 Market-based demand-driven innovation: seven key principles and illustrative case studies

AMNON FRENKEL AND SHLOMO MAITAL

PART II

The supply-side dimensions

5 Characterizing the evolution of the EU R\&D intensity gap using data from top $R \& D$ performers

$I_{2}$ STANČÍK AND F. BIAGI

6 Good governance, firm performance and policy recommendations: is the shareholder value counter-revolution obsolete? 
x Contents

7 The geography of inter-firm knowledge spillovers in bio-tech

RON BOSCHMA, PIERRE-ALEXANDRE BALLAND AND

DIETER KOGLER

8 Social capital and the innovative performance of Italian provinces

RICCARDO CRESCENZI, LUISA GAGLIARDI AND

MARCO PERCOCO

PART III

Innovation and systemic technology policy

9 The ontology of complexity and the implications for innovation policy

VERÓNICA ROBERT AND GABRIEL YOGUEL

10 The multi-dimensional additionality of innovation policies: a multi-level application to Italy and Spain

ALBERTO MARZUCCHI AND SANDRO MONTRESOR

11 Innovation policies as engines of economic growth: standard lessons and systemic insights for Bulgaria

12 The emergence of wind energy in Spain: a review of the policy mix

CRISTIAN MATTI AND DAVIDE CONSOLI

13 The role of environmental policy for eco-innovation: theoretical background and empirical results for different countries

JENS HORBACH

14 Innovation policy for knowledge production and R\&D: the investment portfolio approach

SUSANA BORRÁS AND CHARLES EDQUIST

15 Conclusions and policy implications 


\section{Figures}

2.1 Effect of product quality on the disposable income created in the economic system

2.2 Influence of the different preference systems on the rate of growth of income

2.3 Influence of the different preference systems on the rate of growth of employment

2.4a Product quality, as measured by the services supplied by a product $\left(\mathrm{Y}_{\mathrm{i}}\right)$ in the low-quality (thin curve) or high-quality (bold curve) case

2.4b Effect of product quality on sectoral demand 33

2.4c Effect of product quality on sectoral output 33

2.4d Effect of product quality on sectoral wages 33

$2.4 \mathrm{e}$ Effect of product quality on the quantity of human capital used in a sector

2.4f Effect of product quality on the quality of human capital used in a sector

2.5 Effect of product quality on the disposable income created in the economic system for the low-quality case (a) and for the high-quality case (b)

2.6 Effect of product quality on the aggregate rate of income growth

2.7 Effect of product quality on the aggregate rate of employment growth

2.8 Effect of changing the weight $k_{H i}$ of $\mathrm{Hi}$ in the production function for different values of barrier in human capital $B_{h i}$

2.9 Effect of changing the wage parameter $k_{w}$ for different values of barrier in human capital

2.10 Employment for the LQ (light line) and HQ (heavy line) scenarios for $B_{h i}=0.5$ and $k_{H i}=2.0$

2.11 Income curves for the LQ (grey curves) and HQ (black curves) cases showing the impact of different preferences on income generation. The parameter settings correspond to the standard scenario 


\section{xii Figures}

2.12 Income curves for the LQ (grey curves) and HQ (black curves) cases showing the impact of different preferences on income generation. The parameter settings correspond to higher values of the $B_{h i}$ barrier in human capital and in the weight of human capital in the production function

3.1 Smithian view on demand-pulling mechanism

3.2 Kaldorian demand-pulling mechanism

3.3 Schmookler's demand-pulling mechanism

3.4 Market for external knowledge and equilibrium in the presence of knowledge externalities

3.5 General equilibrium consequences of knowledge externalities

3.6 Demand pull and adaptive vs. creative reaction

4.1 The three value disciplines

4.2 Markets of 1,000

4.3 Nokia's $2 \times 2$ market map

4.4 Lead users as a source of quality

5.1 Decomposition of the R\&D intensity gap into structural and intrinsic components

5.2 The share of structural component in the total R\&D intensity gap

5.3 R\&D intensity gap across regions and sectors

5.4 Sector weights across regions

7.1 Degree distribution (2007-2010)

7.2 Knowledge exchanges between the top 20 actors

$$
\text { (2007-2010) }
$$

8.1 Growth rate of patents (per million inhabitants), 2001-2007

8.2 Social capital, composite indicator, 2001

A.8.1 Moran's I test on the dependent variable (patents' growth rate)

A.8.2 Moran's I test for the regression residuals

9.1 The relationship between the two traditions of complexity in the economic history and the five evolutionary groups

10.1 The multi-dimensional additionality of innovation policies

10.2 Multi-level additionality of innovation policies

10.3 The multi-level additionality of innovation policies, cross-dimensional averages

10.4 The multi-dimensional additionality of innovation policies, total cross-level effects

11.1 Dynamic export profile of Bulgaria

11.3 The percentage of Bulgarian patents with international co-inventors

11.4 Distribution of Bulgarian scientific publications

11.5 Relative impact index in selected disciplines for Bulgaria and comparators 
12.1 Wind energy cumulated capacity (selected countries)

12.2 Total wind farms and wind turbines in Spain, 2003-2010 312

12.3 Wind farm technologies and forms of know-how 314

12.4 Wind power installed capacity (MW), Spanish regions, $2011 \quad 318$

12.5 Wind power industrial sites, $2013 \quad 320$

12.6 Market concentrations in the Spanish wind energy market: main actors

12.7 Concentration of wind power capacity at regional level 322

12.8 Distribution of energy research infrastructure, 2012323

12.9 Evolution of energy balance in Spain: ordinary and special regime, 1997-2012

12.10 Evolution of power capacity in Spanish electricity system: wind power, ordinary and special regime, 1997-2012

12.11 Evolution of total subsidies granted by FIT scheme and RES-E produced with wind resources, 1998-2012

12.12 Evolution of average price compensation, 1998-2012

12.13 Grants and energy produced as part of the total, 2004 and 2012

12.14 Evolution of regional normative related to renewable energy in CCAA, 1990-2010 (four-year moving average)

$\begin{array}{ll}\text { 12.15 Main technological components of a wind turbine } & 344\end{array}$

12.16 Wind farm technologies and forms of know-how 345

14.1 Mapping R\&D organizations in innovation systems - a generic illustration 


\section{Tables}

A.2.1 Parameter sets on the rate of growth of income and on the rate of growth of employment

4.1 List of case studies

5.1 Number of companies by year

5.2 Summary statistics

5.3 Sector division by ICB1 categories and R\&D intensity

5.4 Regional division

6.1 Evidence on the impact of good governance on company performance

6.2 Evidence on the impact of good governance on innovation

7.1 Changes in citation ties between observations

7.2 Key players in biotech: top 20 centrality scores (2007-2010)

7.3 Structural characteristics of knowledge spillovers

7.4 Structural variables

7.5 Descriptive statistics of the control variables

7.6 The determinants of inter-organizational knowledge spillovers, 2008-2010

8.1 Estimation of the empirical model: regional knowledge production function with social capital - annual growth rate of regional patenting (2001-2007)

8.2a First stage regression

$8.2 \mathrm{~b}$ First stage statistics

8.3 Robustness checks (1): estimation of the empirical model -

donations and voluntary associations; annual growth rate of

8.4 Robustness checks (2): correlation between the instrument

A.8.1 Variables list

A.8.2 Further robustness checks (1): estimation of the empirical 
A.8.3 Further robustness checks (2): estimation of the empirical model - regional knowledge production function with social capital; annual growth rate of regional patenting (2001-2007)

9.1 Four dimensions of the ontology of complexity 207

9.2 Two alternative paths of complexity in economic thinking 214

9.3 Assumptions regarding the ontology of complexity by thematic group/author

10.1 Additionality of Italian policies 252

10.2 Additionality of Spanish policies 256

A.10.1 Italy and Spain in the CIS4: descriptive statistics 264

A10.2 Probit estimation of propensity scores 265

11.1 Main export destinations for Bulgaria 279

11.2 The structural shift and rebirth of Bulgarian international $\begin{array}{ll}\text { patenting } & 284\end{array}$

11.3 Scientific specialization index for Bulgaria 286

11.4 Firm internal capabilities development across innovators and exporters 290

11.5 External drivers and obstacles for firm innovation and exports 291

A.11.1 Top 15 products contributing to Bulgarian export $\begin{array}{ll}\text { sophistication (EXPY) } & 300\end{array}$

A.11.2 Scientific publications and citation totals 301

A.11.3 Top five Bulgarian 'hot' scientific papers in terms of
citations

A.11.4 Top Bulgarian institutions in terms of scientific publications 303

A.11.5 Top scientific partners in Bulgarian publications L 304

12.1 Global market shares - main wind turbine manufacturers 316

12.2 National market share of wind power capacity - developers and wind turbine manufacturers

12.3 Industrial sites specialized in wind energy technologies: Spain, 2006-2013

12.4 Distribution of policy instruments among regions by category

12.6 Performance of EU/OECD countries in the introduction of renewables

12.7 Taxonomy of demand-side policy and instruments 338

12.8 Typologies of policy instruments for renewable energy 342

$\begin{array}{ll}13.1 \text { Determinants of eco-innovation } & 350\end{array}$ 


\section{Contributors}

Cristiano Antonelli, Department of Economics, University of Turin and BRICK Collegio Carlo Alberto.

Pierre-Alexandre Balland, Urban and Regional Research Centre Utrecht (URU).

F $\mathbf{2}$ Biagi, JRC-IPTS European Commission, University of Padua and SDA Bocconi.

Susana Borrás, Copenhagen Business School.

Ron Boschma, Lund University - CIRCLE.

Davide Consoli, INGENIO (CSIC-UPV), Valencia (Spain).

Riccardo Crescenzi, Departme f Geography and Environment \& SERC, London School of Economics

Francesco Crespi, Professor at the Department of Economics of Roma Tre University, and Research Associate at the Bureau of Research on Innovation, Complexity and Knowledge (BRICK), Collegio Carlo Alberto, Italy.

Charles Edquist, Lund University - CIRCLE.

Amnon Frenkel, Samuel Neaman Institute for Advanced Studies in Science and Technology Technion - Israel Institute of Technology.

Luisa Gagliardi Department of Geography and Environment, London School of Economics $\Omega$

Agnieszka Gehringer, Department of Economics, University of Göttingen.

Jens Horbach, University of Augsburg.

Dieter Kogler, University College Dublin.

Jackie Krafft, University of Nice Sophia Antipolis, CNRS-GREDEG.

Sorin M.S. Krammer, University of Groningen, Faculty of Economics and 
Contributors xvii

Shlomo Maital, Samuel Neaman Institute for Advanced Studies in Science and Technology Technion - Israel Institute of Technology.

Alberto Marzucchi, Gathe Universitan,

Cristian Matti, INGENIO (CSIC-UPV), Valencia (Spain).

Sandro Montresor, KORE University of Enat.

Marco Percoco, Department of Policy Analysis and Public Management, Università Bocconi.

Andreas Pyka, University of Hohenheim, Economics Institute, Wollgrasweg 23, D-70599 Stuttgart, Germany.

Francesco Quatraro, Associate Professor at the University of Nice Sophia Antipelis, France.

Jacques-Laurent Ravix, University of Nice Sophia Antipolis, CNRS-GREDEG.

Verónica Robert, Universidad Nacional de General Sarmiento.

Pier Paolo Saviotti, INRA-GAEL, Université Pierre Mendès-France, BP 47, 38040 Grenoble, France. GREDEG CNRS, Sophia Antipolis, Valbonne, France; Eindhoven Centre for Innovation Studies (ECIS), School of Innovation Sciences, Eindhoven University of Technology, P.O. Box 513, NL5600MB Eindhoven, The Netherlands; Temporary Research Fellow, Institute of Advanced Studies (IAS), Durham University, Durham, UK.

J.Stančík, JRC-IPTS European Commission.

Gabriel Yoguel, Universidad Nacional de General Sarmiento. 


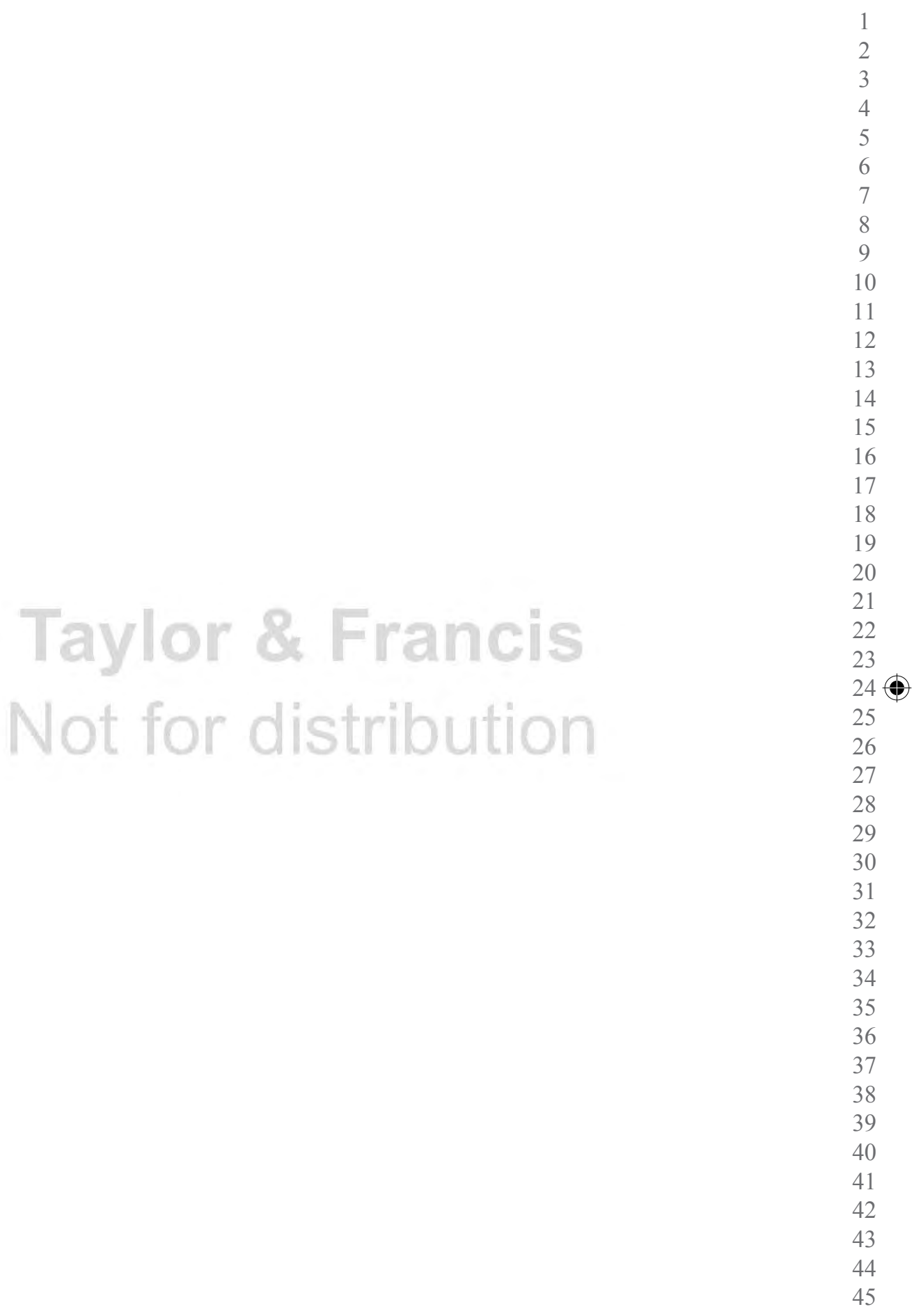

